\title{
Effect on mortality of treatment method and surgery time for hip fracture patients aged over 65 years
}

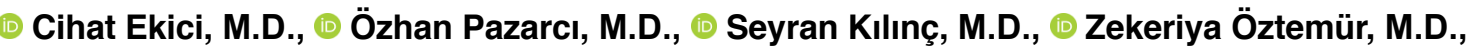 \\ 다 Hayati Öztürk, M.D., 두) Gündüz Tezeren, M.D., 두) Okay Bulut, M.D.
}

Department of Orthopaedics and Traumatology, Cumhuriyet University Faculty of Medicine, Sivas-Turkey

\begin{abstract}
BACKGROUND: This study aimed to evaluate the effects on mortality of implant selection used and time to surgery in patients aged over 65 years operated for hip fractures.

METHODS: A total of 301 patients aged over 65 years were investigated in this study. Patients were divided into three groups as follows: Group I cemented hemiarthroplasty $(\mathrm{CH})$, Group 2 cementless hemiarthroplasty (CLH), and Group 3 proximal femoral nail (PFN). Time of surgery, fracture and demographic information were retrospectively recorded.

RESULTS: After removing 59 patients with missing information, this study included 242 patients. Mean age of patients was 80.5 years. When patient groups were examined according to treatment method, Group I ( $n=146)$ comprised 60.3\%, Group 2 ( $n=54$ ) comprised $22.3 \%$ and Group $3(n=42)$ comprised $17.4 \%$ of the study group. There was no significant difference in survival between the patients operated in the first 48 hours and the patients operated later $(p=0.834)$. There was an effect on the survival of treatment implant selection $(p=0.016)$. Patients with $\mathrm{CH}$ were observed to survive longer than patients with $\mathrm{CLH}$ and PFN.
\end{abstract}

CONCLUSION: Operation in the first 48 hours was not observed to affect mortality. Additionally, while sex and age were found to be effective on mortality, implant selection was also concluded to affect mortality.

Keywords: Hemiarthroplasty; hip fracture; mortality; proximal femoral nail; surgery time.

\section{INTRODUCTION}

All future population projections predict increasing elderly populations, ${ }^{[I]}$ which shows that there will be an increase in the frequency of elderly patients with osteoporotic hip fractures. ${ }^{[2]}$ The main principles of treatment in osteoporotic hip fracture patients are to provide appropriate treatment to prevent mortality and morbidity and to rapidly make the patient mobile. ${ }^{[3]}$

Treatment for hip fractures over 65 years is determined considering the physiologic age of the patient, activity, presence of systemic diseases, bone quality and fracture displacement degree. Among treatment selections for osteoporotic hip fracture patients, proximal femoral nail (PFN) and cemented hemiarthroplasty $(\mathrm{CH})$ or cementless hemiarthroplasty $(\mathrm{CLH})$ are commonly chosen. These treatment methods involve advantages and disadvantages. In the literature, there are studies investigating the correlation between the implant used for hip fracture treatment and mortality. ${ }^{[4-6]}$ However, to date, to our knowledge, there is no gold standard treatment defined for elderly hip fracture patients.

There are many studies investigating the effects of time of surgery on mortality in hip fractures. ${ }^{[5,7]}$ A significant degree of reduction for mortality was reported for hip fractures operated within the first 48 hours. ${ }^{[8]}$ Additionally, there are studies reporting the opinion that elderly patients should be operated at the earliest possible time allowed by their medical status. ${ }^{[9,10]}$ In this context, the hypothesis we tested in this

Cite this article as: Ekici C, Pazarcı Ö, Kılınç S, Öztemür Z, Öztürk H, Tezeren G, et al. Effect on mortality of treatment method and surgery time for hip fracture patients aged over 65 years. Ulus Travma Acil Cerrahi Derg 2020;26:439-444.

Address for correspondence: Özhan Pazarcı, M.D.

Cumhuriyet Üniversitesi Tıp Fakültesi, Ortopedi ve Travmatoloji Anabilim Dalı, Sivas, Turkey

Tel: +90 346 - 219 II 56 E-mail: dr.pazarci@gmail.com

Ulus Travma Acil Cerrahi Derg 2020;26(3):439-444 DOI: 10.14744/tjtes.2020.8I780 Submitted: 26.06.2019 Accepted: II.02.2020 Online: I3.05.2020

Copyright 2020 Turkish Association of Trauma and Emergency Surgery 
study is the question of whether implant selection or time of surgery is effective on mortality. Thus, this study aims to evaluate the effects on mortality of the implant type used and the time of surgery in patients aged over 65 years operated for hip fracture.

\section{MATERIALS AND METHODS}

Local ethics committee permission was received on 26.03.2019 numbered 2018-03/27. This study included patients attending our clinic for hip fracture from January 2012 to January 2016. Of these, patients with less than two years follow-up and under the age of 65 were excluded from this study. A patient pool of 301 patients older than 65 years was formed. Fifty-nine patients without patient follow-up information or who left clinical follow-up were excluded. Thus, 242 patients were investigated (Table I). Patients were divided into three groups according to implant selected for treatment as $\mathrm{CH}, \mathrm{CHL}$ and PFN (Figs. I-3). The demographic information, comorbid diseases, American Society of Anesthesiologists (ASA) score, time of surgery, type of anesthesia, type of treatment, duration of hospital stay, duration of fol-

Table I. Methodology flow chart

I. This study included 30 I patients aged over 65 years with hip fracture from January 2012 to 2016 .

2. Preop and postop follow-up radiographs examined in the PACS system and 59 patients without follow-up radiographs were excluded from this study.

3. Fractures classified according to AO.

4. Patient information collected from files retrospectively.

- Demographic data

- Comorbid diseases

- ASA score

- Time of surgery

- Type of anesthesia

- Form of treatment

- Hospital stay

- Complications

5. Time of death recorded for patients from the national mortality records.

6. Data from 242 patients were investigated in three groups according to the treatment method.

\begin{tabular}{ccc}
\hline Group I & Group 2 & Group 3 \\
I46 patients with & 54 patients with & 42 patients with \\
$\mathrm{CH}$ & CLH & PFN \\
\hline
\end{tabular}

PACS: Picture Archiving \& Communication Systems; AO: Arbeitsgemeinschaft für Osteosynthesefragen; ASA: American Society of Anesthesiologists; $\mathrm{CH}$ : $\mathrm{Ce}-$ mented hemiarthroplasty; CLH: Cementless hemiarthroplasty; PFN: Proximal femoral nail.
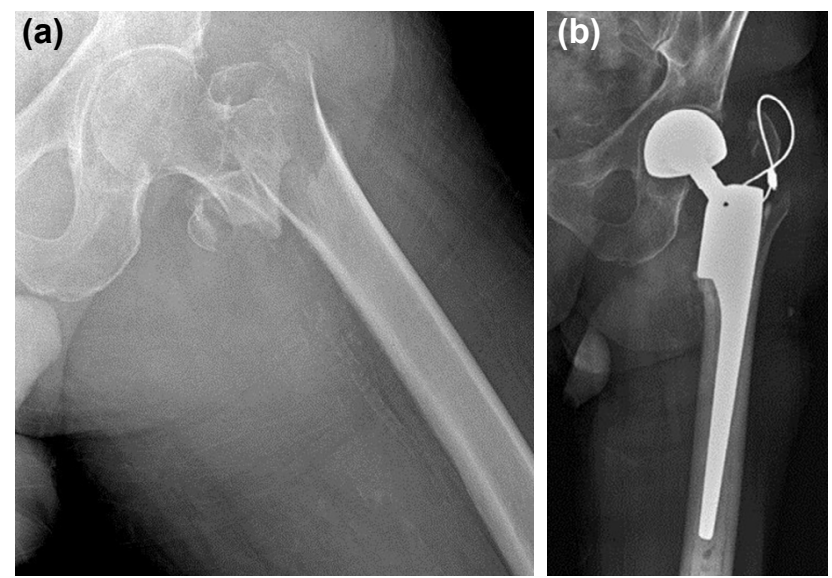

Figure 1. 82-year-old patient with cemented hemiarthroplasty $(\mathrm{CH})$ radiographs (a) preop, (b) postop.
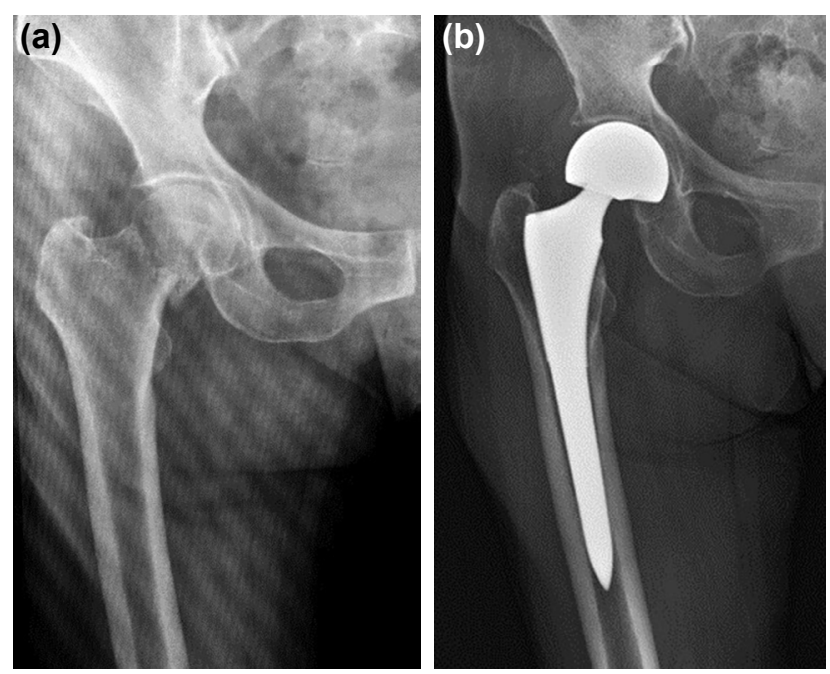

Figure 2. Radiographs of a 70-year-old patient with cementless hemiarthroplasty (CLH) (a) preop, (b) postop.


Figure 3. Radiographs of a 75-year-old female patient who underwent proximal femoral nail (PFN) (a) preop, (b) postop.

low-up and presence of complications were recorded from patient files. 
Preop and postop radiography of patients was investigated using our hospital's Picture Archiving \& Communication Systems (PACS) system. The time of death of patients was noted by searching the National Mortality Report System (MRS) on 15 May 2018, with survival noted. Fractures were classified according to the Arbeitsgemeinschaft für Osteosynthesefragen $(\mathrm{AO})$ classification.

The SPSS (v. 22.0) statistical program was used to analyse the data in this study. Numerical data were given as mean and standard deviation, while categorical data were given as frequency and percentage. Statistical comparison of means used the t-test, with the chi-square test or Fisher's exact test used for comparison of frequencies. Additionally, patient survival was evaluated using Kaplan-Meier survival analysis. Statistical analysis of differences between group survival used the log-rank test. $\mathrm{P}$-values smaller than 0.05 were accepted as statistically significant.

\section{RESULTS}

This study included 242 patients, with 136 females and 106 males. Mean age of patients was 80.5 years (65-100). Mean follow-up duration was 30.9 months (0-76). There were 69 cases $(28.5 \%)$ with at least one comorbid disease, 67 cases $(27.6 \%)$ with at least two comorbid diseases and 79 cases (32.6\%) with three or more comorbid diseases.

ASA scoring distribution was six patients (2.5\%) with ASA I, I06 patients (43.8\%) with ASA II, I I 8 patients (48.8\%) with ASA III and 12 patients (4.9\%) with ASA IV. There was no ASA $V$ case. Of patients, $68.1 \%(n=165)$ had femoral intertrochanteric fracture and $31.9 \%(n=77)$ had femoral neck fracture. The mean duration of hospital stay was 12.3 days (3-66). Of patients, 59 (24.4\%) were operated in the first 48 hours. For anesthesia, 175 patients (72.3\%) had general anesthesia and 67 patients (27.7\%) had spinal anesthesia administered. When patient groups are examined according to treatment method, Group I $(\mathrm{CH}, \mathrm{n}=\mathrm{I46})$ comprised $60.3 \%$, Group 2 (CLH, n=54) comprised 22.3\% and Group 3 (PFN, $\mathrm{n}=42$ ) comprised $17.4 \%$ of the study group. Three patients had postop prosthesis infection, and 2 had revision due to implant failure. At the time of the study, 98 patients $(40.4 \%)$ were surviving, while 144 patients (59.6\%) were exitus. The general mortality rate mean was 19 months ( 0 days-69 months).

In the three groups, it was observed that operation in the first 48 hours did not affect mortality $(p=0.649)$. A significant difference was identified in first-year mortality rates according to sex, and these rates were $13 \%$ females and $29 \%$ males $(p<0.05)$. The mean hospital stay for patients who died within the first year was 14 days (SD: 10.57), while this value was II.9 days for surviving patients (SD: 6.02) $(p<0.05)$. Also, the type of treatment was found to be statistically significant in this period $(p<0.05)$. Of all patients with the cemented hip prosthesis, 22 (15\%) died within 36 months or later, while five patients (II\%) in the PFN group and only one patient (I.8\%) in the cementless hip prosthesis-patient died in this period (Table 2). Of the surviving 98 patients, the mean age was 78.3 years, while the mean age of the 144 exitus patients was 81.9 years $(p<0.05)$. The firstyear mortality rate was $29 \%$, with general survival of our patients was $19 \%$ (Fig. 4).

When parameters affecting general survival are investigated, ASA score, presence and number of comorbid diseases, fracture type, and sex differences were not observed to have statistically significant effects on survival. The patients operated in the first 48 hours had no statistically significant difference in survival compared to those operated later $(p=0.834)$. There was a statistically significant effect on the survival of

Table 2. Comparison of the factors affecting mortality

\begin{tabular}{|c|c|c|c|c|c|c|c|}
\hline \multirow[t]{2}{*}{ Parameters } & \multicolumn{7}{|c|}{ P-values* } \\
\hline & Month & $0-1$ & $1-12$ & $12-24$ & 24-36 & $>36$ & Total \\
\hline I. Time of the surgery & & 0.576 & 0.924 & 0.301 & 0.910 & 0.345 & 0.649 \\
\hline 2. Treatment method & & 0.158 & 0.253 & 0.814 & 0.584 & 0.034 & 0.145 \\
\hline 3. ASA score & & 0.424 & 0.598 & 0.936 & 0.085 & 0.919 & 0.178 \\
\hline 4. Presence of the comorbid diseases & & 0.229 & 0.488 & 0.172 & 0.397 & 0.613 & 0.339 \\
\hline 5. Type of the anesthesia & & 0.110 & 0.922 & 0.607 & 0.645 & 0.824 & 0.883 \\
\hline 6. Fracture type & & 0.310 & 0.894 & 0.811 & 0.823 & 0.520 & 0.950 \\
\hline 7. Complications & & 0.007 & 0.782 & 0.893 & 0.864 & 0.628 & 0.297 \\
\hline 8. Mean age & & 0.609 & 0.071 & 0.133 & 0.058 & 0.771 & 0.001 \\
\hline 9. Sex & & 0.149 & 0.003 & 0.825 & $0.87 I$ & 0.546 & 0.086 \\
\hline 10. Duration of the hospital stay & & 0.526 & 0.049 & 0.774 & 0.408 & 0.337 & 0.448 \\
\hline
\end{tabular}

"P-values smaller than 0.05 were accepted as statistically significant. ASA: American Society of Anesthesiologists. 


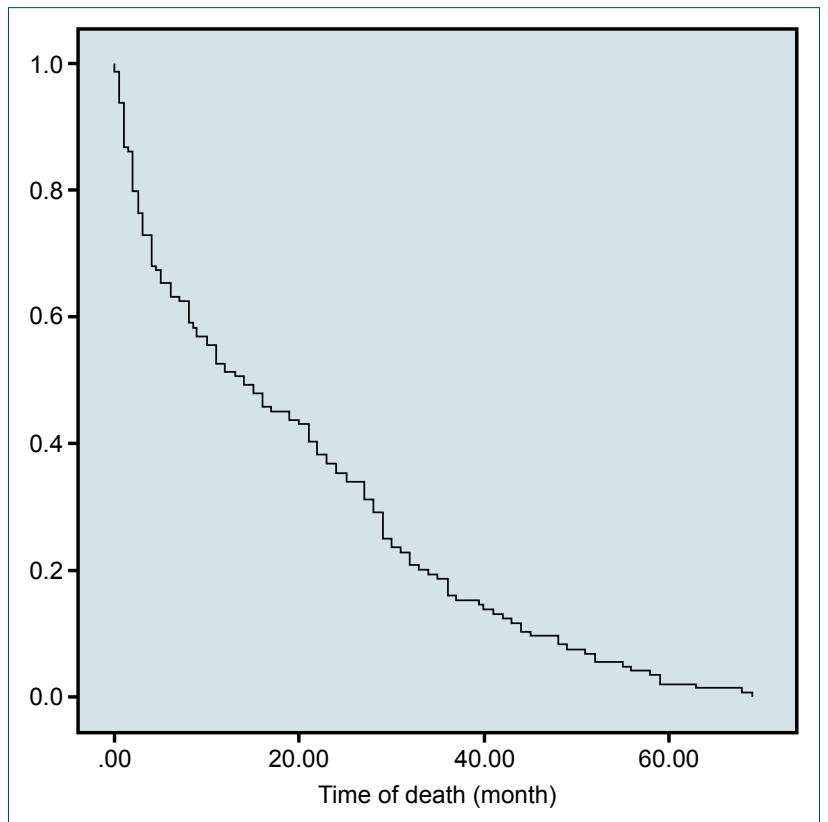

Figure 4. Graph of the general survival.

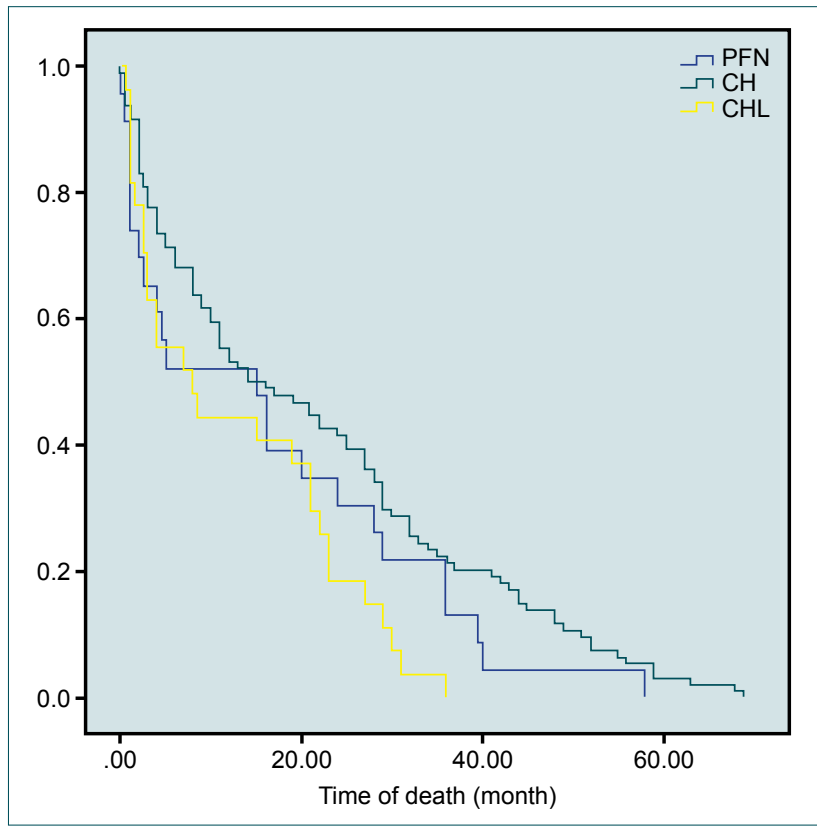

Figure 5. Graph of survival according to treatment method. PFN Proximal femoral nail; $\mathrm{CH}$ : Cemented hemiarthroplasty; $\mathrm{CLH}$ : $\mathrm{Ce}-$ mentless hemiarthroplasty.

implant choice for treatment $(p=0.016)$. Patients with $\mathrm{CH}$ were observed to have longer survival compared to those with CHL and PFN (Fig. 5).

\section{DISCUSSION}

The strongest aspect of our study is the assessment of the effects on mortality of the use of different implants and the time of surgery together for the treatment of elderly hip fracture patients. With the increase in the elderly population, hip fracture cases have become a public health problem. ${ }^{\left[1,{ }^{112]}\right.} \mathrm{High}$ mortality and morbidity rates observed in elderly patients and increased treatment costs illustrate the importance of this problem. ${ }^{[13]}$ In the literature, there are still debates about the gold standard treatment and ideal surgery time for hip fracture cases. ${ }^{[8-10]}$ Our study shows that implant selection has a statistically significant effect on survival.

Patients in our study series were $56 \%$ female and $44 \%$ male. Males were observed to have fewer hip fractures compared to females; however, mortality rates were observed to be higher. Investigation of survival, according to sex in hip fracture patients, found shorter survival in males compared to the female sex. ${ }^{[14]}$ Similar to our study, Schnell et al..$^{[15]}$ found higher two-year mortality in the male sex. Additionally, our study showed that long hospital stays affected mortality, especially in the period from I-12 months. Long hospital stays were shown to have negative effects on mortality in the literature. ${ }^{[16]}$ Our view is that the patient should be rehabilitated and discharged in a short period postoperatively.

Our study found that age was a significant factor affecting general mortality. A study conducted by Forni et al. ${ }^{[17]}$ found that age was the most important factor for mortality in the first month and reported an $8.4 \%$ increase in mortality with each year of age increase for patients over 65 years. A study carried out by Paksima et al. ${ }^{[18]}$ showed that age was the most important factor for mortality, consistent with the results of our study. Our opinion is that all mortality factors should be considered, especially in patients with advanced age. All mortality risks should be minimized as much as possible.

Of our patients, $24.4 \%$ were operated within the first 48 hours. Contrary to the literature, no significant correlation was observed between mortality and time. However, there are studies supporting our research data in the literature. This rate is similar to the large series by Kenzora et al. ${ }^{\left[{ }^{[9]}\right.}$ Our clinic generally operates on patients in the earliest period allowed by their medical status, through operation in the first 48 hours was not shown to have a significant effect on mortality. A study conducted by Sasabuchi et al. ${ }^{[20]}$ found an effect on mortality for 5-day delays in surgery when they controlled for additional variables, including age, chronic diseases and dementia. Al-Ani et al., ${ }^{[2]]}$ in a study with 850 patients, found no difference in mortality for patients operated in 24, 36 and 48 hours.

In our study, mortality in the first 30 days was $7.8 \%$, with first-year mortality of $19 \%$. These rates are similar to the literature. A study carried out by Forni et al. ${ }^{[17]}$ about mortality in the first month after hip fracture in the geriatric patient group found this rate was $4.9 \%$. Schnell et al. ${ }^{[1]}$ found a $21.2 \% \mathrm{I}$-year mortality rate in a study of hip fracture patients over 60 years of age. The authors were of the opinion that elderly hip fracture patients and their relatives should be wellinformed about mortality preoperatively. 
The effects of implant selection used for treatment on mortality are known. Ravikumar et al. ${ }^{[22]}$ investigated the longterm outcomes of internal fixation, hemiarthroplasty and total hip prosthesis for hip fractures and showed the first 2-month mortality was $12 \%$ for internal fixation and $15 \%$ for hemiarthroplasty. Mortality in the 12 months was $25 \%$ for internal fixation and $27 \%$ for hemiarthroplasty. However, though internal fixation was superior for first-year survival, internal fixation was not shown to be superior concerning mortality in the long term. Different studies have shown that 5-week mortality for cemented hip prosthesis was higher; however, the difference in mortalities balanced after the $3^{\text {rd }}$ month. ${ }^{[23]}$ As seen in the literature, there is no gold standard treatment recommended for hip fractures. Our study shows that for long-term survival, $\mathrm{CH}$ is superior. There is a need for randomized controlled clinical studies to suuport the data from our study. Commonly in the literature, there are studies that have investigated the effects of implant selection on mortality generally retrospectively.

In our series, the deep infection rate was 1.2\%. A study by Partanen et al. ${ }^{[24]}$ of patients operated for a hip fracture found that deep infection rates were 1.3\%, similar to our study. The implant failure was $4.7 \%$ in Group 3. Görmeli et al. ${ }^{[5]}$ found that the revision rates due to various reasons, such as implant failure or dislocation, was $11.7 \%$ for PFN, while this rate was $2.6 \%$ for hemiarthroplasty. Our conclusion is that more complications were identified for patients undergoing hemiarthroplasty due to longer surgery duration and larger surgical incision. Many implant comparison studies have emphasized that complications are observed less in patients with PFN. ${ }^{[25]}$ Many methods are recommended in the literature to avoid these complications. For example, the use of double scopy during PFN surgery is reported to reduce the surgical duration and complication risks. ${ }^{[26]}$ If the surgeon chooses to use PFN, they should choose one of these different designs. [27-29] Another important situation is the anesthesia type and pain management administered to the patient. ${ }^{[30]}$ Different from the literature, in our study, there was no significant correlation found between the form of anesthesia and mortality. There are publications stating that general anesthesia is linked to more mortality in this patient group; however, it can be said that this was observed more in patients with high risk related to cardiac causes. ${ }^{[31]}$

The authors are aware of the limitations of this study. The first limitation is that this study is retrospective. Additionally, the decisions about implant selection for patients were made according to surgeon choice and experience. There is a need for randomized prospective studies in this area. The evaluation of mortality in patients with different ASA scores may be seen as a limitation. However, the difficulty in creating homogeneous groups concerning the ASA score cannot be ignored. Additionally, the distribution of ASA scores among patients in our study group is similar to other studies in the literature. ${ }^{[32]}$

\section{Conclusion}

Operation in the first 48 hours was not observed to affect mortality. Additionally, while sex and age affected mortality, it was concluded that implant selection also affected mortality. There is a need for prospective controlled studies in this field.

Ethics Committee Approval: Approved by the local ethics committee.

Peer-review: Internally peer-reviewed.

Authorship Contributions: Concept: C.E., Ö.P.; Design: Ö.P., S.K.; Supervision: G.T., Ö.P.; Fundings: Ö.P.; Materials: Z.Ö., H.Ö.; Data: O.B., G.T. Analysis: Ö.P., O.B.; Literature search: H.Ö., Z.Ö.; Writing: Ö.P., C.E.; Critical revision: O.B., H.Ö.

\section{Conflict of Interest: None declared.}

Financial Disclosure: The authors declared that this study has received no financial support.

\section{REFERENCES}

1. Beğer T, Yavuzer H. Yaşlılık ve Yaşlılık Epidemiyolojisi. Klin Gelişim 2012;25:1-3.

2. Urwin SC, Parker MJ, Griffiths R. General versus regional anaesthesia for hip fracture surgery: A meta-analysis of randomized trials. $\mathrm{Br} \mathrm{J}$ Anaesth 2000;84:450-5. [CrossRef]

3. Desteli EE, Imren Y, Erdoğan M, Aydagün Ö. Quality of life following treatment of trochanteric fractures with proximal femoral nail versus cementless bipolar hemiarthroplasty in elderly. Clin Investig Med 2015;38:E63-72. [CrossRef]

4. Khan SK, Kalra S, Khanna A, Thiruvengada MM, Parker MJ. Timing of surgery for hip fractures: a systematic review of 52 published studies involving 291,413 patients. Injury 2009;40:692-7. [CrossRef]

5. Görmeli G, Korkmaz MF, Görmeli CA, Adanaş C, Karataş T, Şimşek SA. Comparison of femur intertrochanteric fracture fixation with hemiarthroplasty and proximal femoral nail systems. Ulus Travma Acil Cerrahi Derg 2015;21:503-8. [CrossRef]

6. Langslet E, Frihagen F, Opland V, Madsen JE, Nordsletten L, Figved W. Cemented versus uncemented hemiarthroplasty for displaced femoral neck fractures: 5-year followup of a randomized trial. Clin Orthop Relat Res 2014;472:1291-9. [CrossRef]

7. Gölge UH, Pazarci O, Kılınç S, Nusran G, Kaymaz B, Göksel F, et al. The treatment of intertrochanteric fractures comparison of PFN and hemiarthroplasty 3-year mortality study. Acta Orthop Belg 2016;82:508-15.

8. Moja L, Piatti A, Pecoraro V, Ricci C, Virgili G, Salanti G, et al. Timing matters in hip fracture surgery: patients operated within 48 hours have better outcomes. A meta-analysis and meta-regression of over 190,000 patients. PLoS One 2012;7:e46175. [CrossRef]

9. Uzoigwe CE, Burnand HG, Cheesman CL, Aghedo DO, Faizi M, Middleton RG. Early and ultra-early surgery in hip fracture patients improves survival. Injury 2013;44:726-9. [CrossRef]

10. Lee DJ, Elfar JC. Timing of Hip Fracture Surgery in the Elderly. Geriatr Orthop Surg Rehabil 2014;5:138-40. [CrossRef]

11. Orces CH. Epidemiology of hip fractures in Ecuador. Rev Panam Salud Pública 2009;25:438-42. [CrossRef]

12. Cooper C, Campion G, Melton LJ 3rd. Hip fractures in the elderly: a world-wide projection. Osteoporos Int 1992;2:285-9. [CrossRef] 
13. Roche JJ, Wenn RT, Sahota O, Moran CG. Effect of comorbidities and postoperative complications on mortality after hip fracture in elderly people: prospective observational cohort study. BMJ 2005;331:1374. [CrossRef]

14. Keene GS, Parker MJ, Pryor GA. Mortality and morbidity after hip fractures. BMJ 1993;307:1248-50. [CrossRef]

15. Schnell S, Friedman SM, Mendelson DA, Bingham KW, Kates SL. The 1-year mortality of patients treated in a hip fracture program for elders. Geriatr Orthop Surg Rehabil 2010;1:6-14. [CrossRef]

16. Shiga T, Wajima Z, Ohe $Y$. Is operative delay associated with increased mortality of hip fracture patients? Systematic review, meta-analysis, and meta-regression. Can J Anaesth 2008;55:146-54. [CrossRef]

17. Forni C, Gazineo D, D'Alessandro F, Fiorani A, Morri M, Sabattini T, Ambrosi E, et al. Predictive factors for thirty day mortality in geriatric patients with hip fractures: a prospective study. Int Orthop 2019;43:275-81. [CrossRef]

18. Paksima N, Koval KJ, Aharanoff G, Walsh M, Kubiak EN, Zuckerman JD, et al. Predictors of mortality after hip fracture: a 10-year prospective study. Bull NYU Hosp Jt Dis 2008;66:111-7.

19. Kenzora JE, McCarthy RE, Lowel JD, Sledge CB. Hip Fracture Mortality. Clin Orthop Relat Res 1984;186:45-56. [CrossRef]

20. Sasabuchi Y, Matsui H, Lefor AK, Fushimi K, Yasunaga H. Timing of surgery for hip fractures in the elderly: A retrospective cohort study. Injury 2018;49:1848-54. [CrossRef]

21. Al-Ani AN, Samuelsson B, Tidermark J, Norling A, Ekström W, Cederholm T, et al. Early operation on patients with a hip fracture improved the ability to return to independent living. A prospective study of 850 patients. J Bone Joint Surg Am 2008;90:1436-42. [CrossRef]

22. Ravikumar KJ, Marsh G. Internal fixation versus hemiarthroplasty versus total hip arthroplasty for displaced subcapital fractures of femur--13 year results of a prospective randomised study. Injury 2000;31:793-7. [CrossRef]

23. Khan RJK, MacDowell A, Crossman P, Keene GS. Cemented or uncemented hemiarthroplasty for displaced intracapsular fractures of the hip - A systematic review. Injury 2002;33:13-7. [CrossRef]
24. Partanen J, Syrjälä H, Vähänikkilä H, Jalovaara P. Impact of deep infection after hip fracture surgery on function and mortality. J Hosp Infect 2006;62:44-9. [CrossRef]

25. Talmaç MA, Görgel MA, Armağan R, Sönmez MM, Özdemir HM. Examining implant superiority in the treatment of simple pertrochanteric fractures of the proximal femur in elderly patients. Ulus Travma ve Acil Cerrahi Derg 2019;25:410-6. [CrossRef]

26. Çelik H, Kara A, Sağlam Y, Türkmen İ, Aykut S, Erdil M. Can double fluoroscopy in the oblique position reduce surgical time and radiation exposure during intertrochanteric femur fracture nailing? Ulus Travma ve Acil Cerrahi Derg 2018;24:581-6. [CrossRef]

27. Zehir S, Şahin E, Zehir R. Comparison of clinical outcomes with three different intramedullary nailing devices in the treatment of unstable trochanteric fractures. Ulus Travma ve Acil Cerrahi Derg 2015;21:46976. [CrossRef]

28. Uzer G, Elmadağ NM, Yıldız F, Bilsel K, Erden T, Toprak H. Comparison of two types of proximal femoral hails in the treatment of intertrochanteric femur fractures. Ulus Travma ve Acil Cerrahi Derg 2015;21:385-91. [CrossRef]

29. Kaynak G, Ünlü MC, Güven MF, Erdal OA, Tok O, Botanlığlu H, et al. Intramedullary nail with integrated cephalocervical screws in the intertrochanteric fractures treatment: Position of screws in fracture stability. Ulus Travma ve Acil Cerrahi Derg 2018;24:268-73. [CrossRef]

30. Uysal Aİ. The effect of early femoral nerve block intervention on preoperative pain management and incidence of postoperative delirium geriatric patients undergoing trochanteric femur fracture surgery: a randomized controlled trial. Turkish J Trauma Emerg Surg 2019;26:109-14. [CrossRef]

31. Karaman Ö, Özkazanlı G, Orak MM, Mutlu S, Mutlu H, Çalışkan G, et al. Factors affecting postoperative mortality in patients older than 65 years undergoing surgery for hip fracture.Ulus Travma ve Acil Cerrahi Derg 2015;21:44-50. [CrossRef]

32. Richmond J, Aharonoff GB, Zuckerman JD, Koval KJ. Mortality risk after hip fracture. J Orthop Trauma 2003;17:53-6. [CrossRef]

\section{ORIJIINAL ÇALIŞMA - ÖZET}

\section{Altmış beş yaş üstü kalça kırığı olgularında tedavi yöntemi ve ameliyata alınma zamanının mortaliteye etkisi}

\section{Dr. Cihat Ekici, Dr. Özhan Pazarcı, Dr. Seyran Kılınç, Dr. Zekeriya Öztemür, Dr. Hayati Öztürk, Dr. Gündüz Tezeren, Dr. Okay Bulut}

Cumhuriyet Üniversitesi Tıp Fakültesi, Ortopedi ve Travmatoloji Anabilim Dalı, Sivas

AMAÇ: Sunulan çalışmada 65 yaş üstündeki kalça kırı̆ı̆ nedeni ile ameliyat edilen hastalarda implant çeşidi ve cerrahi zamanlamanın mortaliteye etkisinin değerlendirilmesi amaçlandı.

GEREÇ VE YÖNTEM: Altmış beş yaş üstü 30 I hasta incelendi. Hastalar Grup I çimentolu hemiartroplasti, Grup 2 çimentosuz hemiartroplasti ve Grup 3 femur proksimal çivi yapılanlar olarak ayrıldı. Ameliyat zamanı, kırık ve demogrofik bilgileri geriye dönük kaydedildi.

BULGULAR: Bilgilerine ulaşılamayan 59 hasta çıkarıldıktan sonra çalışmaya 242 hasta dahil edildi. Hastaların ortalama yaşı 80.5 (65-100) idi. Tedavi yöntemine göre hasta gruplarına bakıldığında; Grup I ( $n=\mid 46) \% 60.3$, Grup 2 ( $n=54) \% 22.3$, Grup $3(n=42) \% 17.4$. Illk 48 saate opere edilenlerle, sonrasında opere edilenler arasında anlamlı bir fark bulunmadı $(p=0.834)$. Tedavide implant seçiminin survey üzerine etkisi vardı $(p=0.016)$. Çimentolu hemiartroplasti yapılan hastaların surveyinin çimentosuz hemiartroplasti ve proksimal femoral çivi (PFN) yapılanlara göre daha uzun olduğu görüldü.

TARTIŞMA: Her üç grupta da ilk 48 saatte ameliyata alınmamanın mortalite üzerinde anlamlı etkisinin olmadığı görüldü. Bunun yanında yaş ve cinsiyet mortalite üzerine etkilidir. Ayrıca implant seçimide mortaliteyi etkilemektedir.

Anahtar sözcükler: Ameliyat zamanı; hemiarthroplasti; kalça kırı̆̆ı; mortality; proksimal femoral nail

Ulus Travma Acil Cerrahi Derg 2020;26(3):439-444 doi: 10.14744/tjtes.2020.81780 